913 液体中で接触する固体壁面の相対運動により固液界面に発生するキャビテーションの観察

\title{
Observation of cavitation on liquid-solid interface caused by relative motion of solid walls contacting in liquid
}

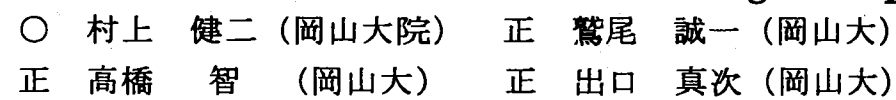

Kenji MURAKAMI, Okayama University, 3-1-1, Tsushimanaka, Okayama City, Okayama Pref.

Seiichi WASHIO, Okayama University

Satoshi TAKAHASHI, Okayama University

Shinji DEGUCHI, Okayama University

\section{1. 緒言}

Key Words : Cavitation inception, Relative motion

伝統的なキャビテーション初生理論の前提である「液体中 に常時遍在する微小気泡核」という考えに対する疑問に端を 発し，著者らの研究室では油を使ったキャビテーション初生 の観察に長年取り組んできた。その結果，キャビテーション は流れのはく離する壁面に突如生まれる極微小空洞から始ま ることを発見し，これまでに様々なはく離流れでその事実を 確認した ${ }^{(1)-(4)}$ ，初生した空洞は成長後分裂し，下流に多くの 微小気泡を供給する。これがいわゆるキャビテーション核と して，下流の乱れにおいて肉眼でも見えるようなキャビテー ション気泡へと成長することも分かっている.

一方，我々のグループは最近流れのはく離とは別の空洞初 生メカニズムが存在することを見出した ${ }^{(5)}$ ．それ流体中で 接触する二つの固体壁面の相対運動に起因するもので，運動 に伴い接触点近傍に突如微小な空洞が生じる。この現象の一 例は，軸受の油膜破断現象として古くから知られていたが， そのメカニズムは伝統的なキャビテーション核の考え説明さ れていた ${ }^{(6)(7)}$. しかし液体に微小気泡が常時遍在するという 前提は自然の摂理に反する，壁面間の相対運動による空洞初 生も流れのはく離におけるそれと同様，固液界面の破れに起 因するのではないかと考えている，今回，固体接触に起因す る空洞初生現象を詳しく調へ，上記の考えを検証する目的で, 新たに装置を作製し，現象の詳しい観察を行った。

\section{2. 実跧装置}

\section{2-1 固体壁面の法線方向相対通動}

二つの接触する壁面の法線方向相対運動を観察する実験装 置を図 1 に示す．密閉円筒容器の内部で，2枚の板バネ(ば ね板鋼，SK4，厚さ $0.5 \mathrm{~mm}$ ）により，図 2 に示す試験片を把 持する，電磁石に電流を流し，板バネに接着したネオジム磁 石との間の反発力で板をたわませて試験片を固定壁に接触さ せる. その後, この電流を切ってバネのカにより試験片が離 れる時の接触面の様子を観察する，容器には固体の接触部を 横及び上の 2 方向から観察できるよう観察空と採光空を設け ている．接触面を浸す液体としては VG46 マシン油(動粘度 $\left.0.73 \mathrm{~cm}^{2} / \mathrm{s} @ 30^{\circ} \mathrm{C}\right)$ を使用する. 実験装置を油圧回路につなぎ， 一回のテストごとに発生，残留する気泡を油を流して除去す るとともに，容器内の加圧にも使用する．また容器内圧力の 減圧は真空ポンプ（到達真空度 $10^{-2} \mathrm{~Pa}$ ) を用いて行う。

キャビテーションの初生を詳細に観察するため, 最大倍率
300 倍の実体顕微鏡と, 最大 40,500FPS まで記録可能な高速 度ビデオカメラを用いる，なお照明にはメタルハライドライ ト（150W）を用いる，実験を行うに当たっては，観察容器部に 十分に油を流して気泡やコンタミナントを取り除いた後，容 器内を 10 気圧で 30 分以上加圧して残留気泡を溶解させる. さらに実験開始前には容器内を真空まで減圧し, 観察視野内 に気泡が現れて来ないことを確認する，なお実験中の容器内 の圧力は，抵抗線ひずみゲージ式圧力計（定格 5.0MPa）を用 いて測定する.
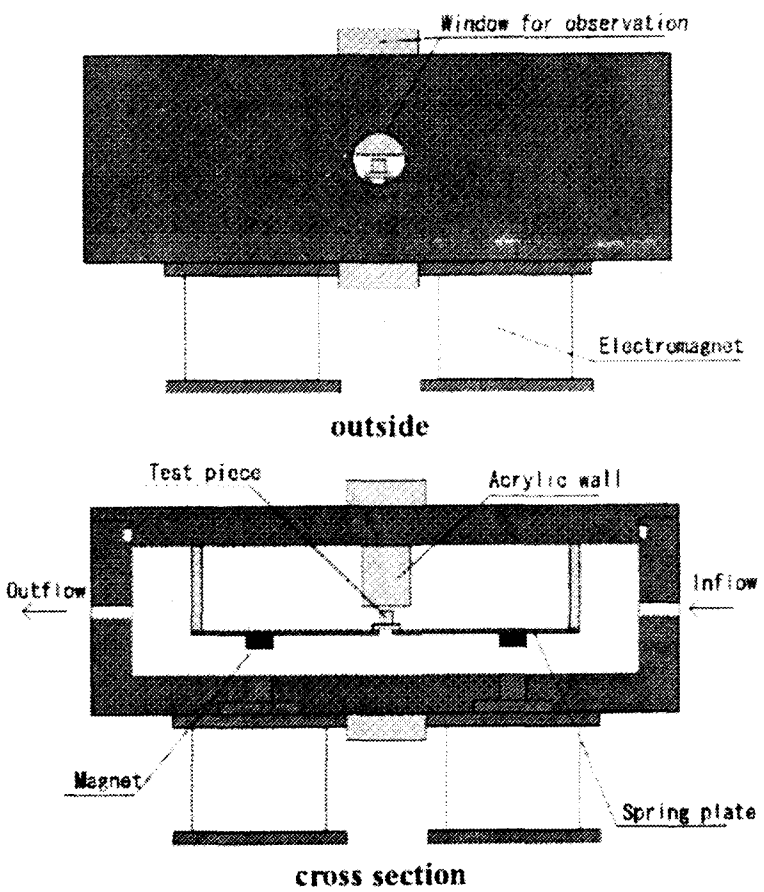

Fig. 1 Experimental vessel to observe cavity inception caused by normal motion of contacting solids

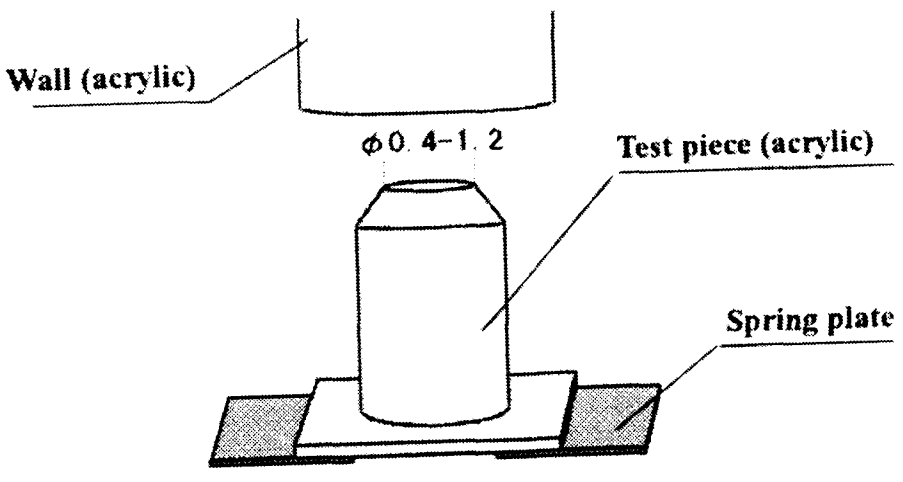

Fig. 2 Test piece and wall 


\section{2-2 固体壁面の接線方向相対通峌}

二つの接触する壁面の接線方向の相対運動を観察する実験 装置を図 3 に示す．油を入れた円筒容器内で速度可変モー夕 に慗いだアクリル製の円盤を回転させ，その表面に試験片を 接触させて，接線方向の相対運動を作り出す，試験片は図の ように直角に繁いだ二枚の板で支持し，水平な板に張った歪 グージで押し付け力を測定する，容器は，固体の接触部を横 及び上の 2 方向から観察できるよう観察空と採光空を設けて おり，固体接触面を中心に観察する．実験を行うに当たって は, 容器内をコンプレッサーで 5 気圧で 30 分以上加圧して残 留気泡を溶解させる．さらに実験開始前には容器内を真空ま で減圧し，観察視野内に気泡が現れて来ないことを確認する。

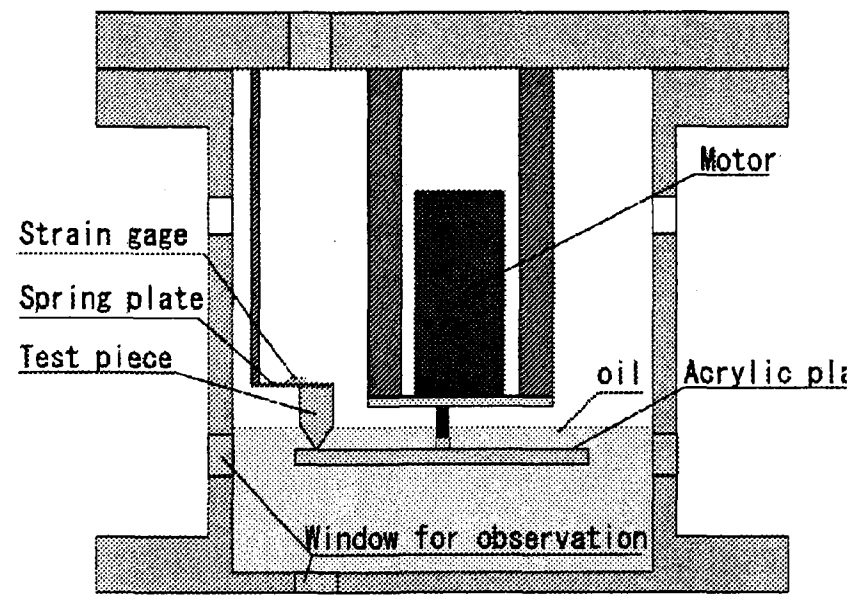

Fig. 3 Experimental vessel to observe cavity inception

\section{3. 実験結果} caused by tangential motion of contacting solids

\section{3-1 固体壁の法線方向通動による初生空洞}

観察容器内を真空に保ち, 固体壁の接触面に焦点を合わせ て試験片 ( $\phi 1.2)$ が接触状態から等加速度運動 $\left(3.6 \mathrm{~m} / \mathrm{s}^{2}\right)$ で法線 方向に遠ざかる様子を上から 4,000FPS で撮影した結果を図 4 に示す。

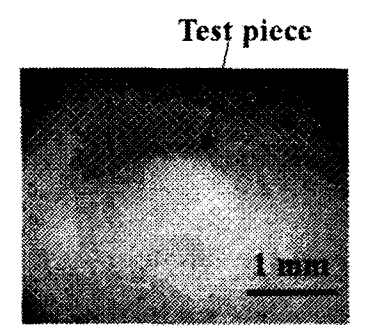

$0 \mathrm{~ms}$

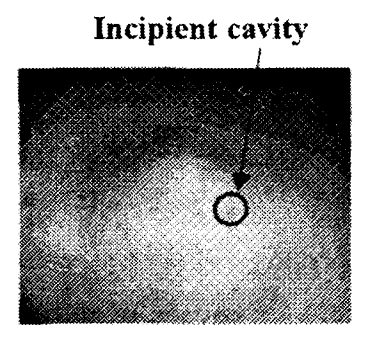

$5 \mathrm{~ms}$ 0s 時は二つの壁面は接触しており，5ms 後にアクリル片が壁 から離れる時に空洞が発生して，その後壁から離れるにつれ て空洞は成長している。

\section{3ー2 固体壁の接線方向運勒による空洞初生}

観察容器内を真空に保ち, 試験片と円盤の接触点に焦点を 合わせて反時計回りにアクリル円板が静止状態から等加速度

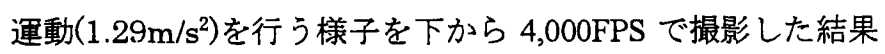
を図 5 に示す。 $0 \mathrm{~s}$ 時は回転開始の瞬間でその $40 \mathrm{~ms}$ 後に接触 点から空洞が発生し，そのまま接触点に停留しながら成長し ている様子がわかる。

\section{4. 結言}

二つの固体壁が接触状態から法線方向に遠ざかる場合, 及 び接触しながら接線方向にす心゙る場合, 両者の接触点近傍で 空洞が初生する. 空洞は真空よりも高い圧力でも初生するが， 圧力が高い程その後の成長は小さく, 大気圧下では空洞は消 滅する.

また二つの固体壁が衝突して跳ね返ると,やはり接触点に 空洞が初生することが確認された。このような空洞からちぎ れた気泡が流れの中でキャビテーションを引き起こすこと が予想される。

謝辞

本研究を行うために不可欠であった実験装置の設計，製作 に関して多大なるご協力,ご助言をいただいた 田村義彦技 術専門職員, 工作センターの技術専門職員の方々に心よりお 礼申し上げます。

\section{参考文献}

(1) 鯂尾 - 他 3 名, 機論(B)65-633(1999), 1643.

(2) 鷲尾 ·他 3 名, 機論(B)66-651(2000), 2912.

(3) 慗尾 - 他 2 名, 機論(B)69-681(2003), 1120.

(4) 荤井 - 他 2 名, 6th International Symp. on Cavitation, 2006

(5) 多田 中四国機械学会, 2006

(6) 中原網光, 潤滑, 26, 3(1981) 146-152

(7) D. Dowson\&C. M. Taylor, Proc. 1st

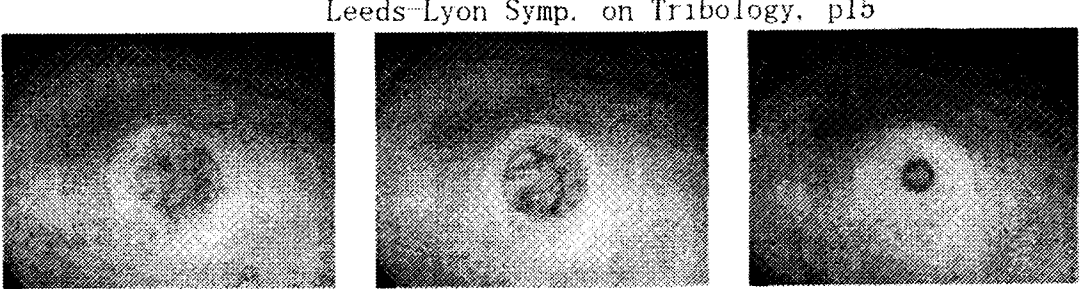

$10 \mathrm{~ms}$

$15 \mathrm{~ms}$

$20 \mathrm{~ms}$

Fig. 4 Cavity produced between two solids moving away in normal direction

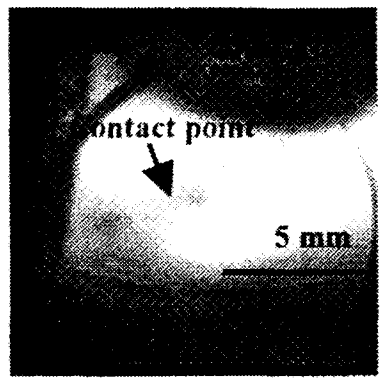

$0 \mathrm{~ms}$

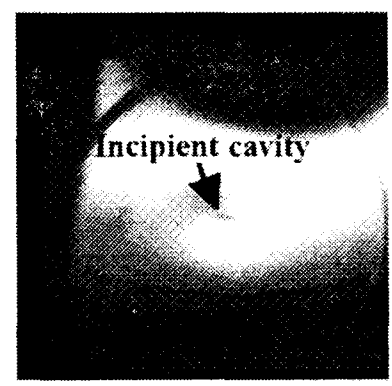

$40 \mathrm{~ms}$

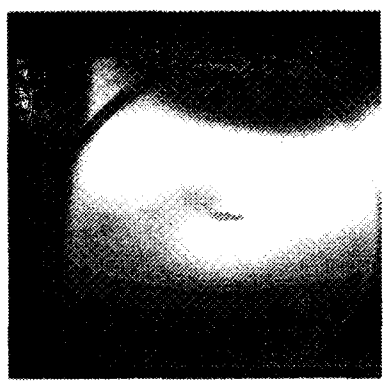

$80 \mathrm{~ms}$

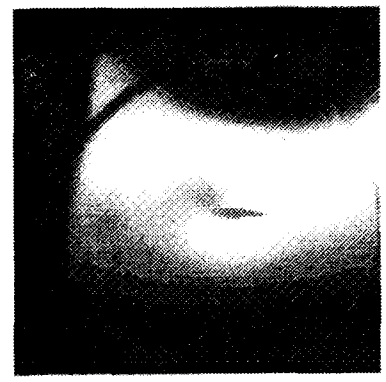

$120 \mathrm{~ms}$

Fig. 5 Cavity produced at contact point when a solid piece is sliding on a plane wall 